\title{
Corrigendum: Exploring the Causality Between Hypothyroidism and Non-alcoholic Fatty Liver: A Mendelian Randomization Study
}

\author{
Shizheng Qiu ${ }^{1 \dagger}$, Peigang $\mathrm{Cao}^{2 \dagger}$, Yu Guo ${ }^{1}$, Haoyu $\mathrm{Lu}^{1}$ and Yang Hu ${ }^{1 *}$ \\ ${ }^{1}$ School of Life Sciences and Technology, Harbin Institute of Technology, Harbin, China, ${ }^{2}$ Department of Cardiovascular, \\ General Hospital of Heilongjiang Province Land Reclamation Bureau, Harbin, China
}

Keywords: mendelian randomization, hypothyroidism, NAFLD, causality, GWAS, SNPs

\section{OPEN ACCESS}

Approved by:

Frontiers Editorial Office

Frontiers Media SA, Switzerland

${ }^{*}$ Correspondence:

Yang Hu

huyang@hit.edu.cn

tThese authors have contributed equally to this work

Specialty section

This article was submitted to Molecular Medicine,

a section of the journal

Frontiers in Cell and Developmental

Biology

Received: 16 May 2021 Accepted: 17 May 2021

Published: 15 June 2021

Citation:

Qu S, Cao P, Guo Y, Lu H and Hu Y (2021) Corrigendum: Exploring the Causality Between Hypothyroidism and Non-alcoholic Fatty Liver: A Mendelian Randomization Study. Front. Cell Dev. Biol. 9:710566. doi: 10.3389/fcell.2021.710566

\section{A Corrigendum on}

Exploring the Causality Between Hypothyroidism and Non-alcoholic Fatty Liver: A Mendelian Randomization Study

by Qiu, S., Cao, P., Guo, Y., Lu, H., and Hu, Y. (2021). Front. Cell Dev. Biol. 9:643582. doi: $10.3389 / f c e l l .2021 .643582$

In the original article, we neglected to include the funder "the National Key R\&D Program of China (2017YFC1201201, 2018YFC0910504 and 2017YFC0907503)", "Heilongjiang Postdoctoral Science Foundation (LBH-Z6064)" and all funding was to "YH". We also incorrectly stated funding from "the Youth program of National Natural Science Foundation of China (Grant No. 61801147)" which should be "the Natural Science Foundation of China (61801147 and 82003553)".

The corrected Funding statement appears below:

This work was supported by the National Key R\&D Program of China (2017YFC1201201, 2018YFC0910504 and 2017YFC0907503), Heilongjiang Postdoctoral Science Foundation (LBHZ6064) and the Natural Science Foundation of China (61801147 and 82003553), all to YH.

The authors apologize for this error and state that this does not change the scientific conclusions of the article in any way. The original article has been updated.

Copyright () 2021 Qiu, Cao, Guo, Lu and Hu. This is an open-access article distributed under the terms of the Creative Commons Attribution License (CC BY). The use, distribution or reproduction in other forums is permitted, provided the original author(s) and the copyright owner(s) are credited and that the original publication in this journal is cited, in accordance with accepted academic practice. No use, distribution or reproduction is permitted which does not comply with these terms. 